\title{
PELATIHAN VIDEO PEMBELAJARAN BERBASIS MULTIMEDIA POWTOON DAN MEDIA UJIAN ONLINE GOOGLE FORMS UNTUK PENUNJANG PELAKSANAAN PEMBELAJARAN ONLINE DI SMPN 1 ANJIR PASAR
}

\author{
Erfan Karyadiputra, Sefto Pratama, Agus Alim Muin \\ Fakultas Teknologi Informasi, \\ Universitas Islam Kalimantan Muhammad Arsyad Al Banjari Banjarmasin \\ Email : erfantsy@gmail.com
}

\begin{abstract}
The Covid-19 pandemic indirectly impacted the transformation of the education system that was once the learning process is still conducted face-to-face, when the pandemic began to be directed into online learning. Community Service aims to help partners, namely SMPN 1 Anjir Pasar who are still having difficulty in utilizing information and communication technology facilities, especially in the online learning process during the Covid-19 pandemic. The priority of partner problems is divided into two parts, namely the first is still a lack of skills in the creation of multimedia-based learning media such as Powtoon so that learning seems monotonous. The second problem is the lack of skills in utilizing Google Forms media as an online test media because it is only limited to using WhatsApp media which of course uses it less efficiently to be used as an online exam medium. With the community service activities to SMPN 1 Anjir Pasar, of course, the hope is to help teachers in understanding and utilizing information and communication technology facilities well and able to use the information technology facilities as a means of supporting media in the implementation of online learning during the Covid-19 pandemic.
\end{abstract}

Keywords : Covid-19, Online, Google Forms, Teachers, Powtoon

\section{PENDAHULUAN}

\section{Pandemi Corona Virus Disease}

(Covid-19) yang melanda di Dunia membawa dampak perubahan yang sangat signifikan diberbagai sektor kehidupan bernegara mulai dari aspek ekonomi, sosial, pendidikan hingga kehidupan sehari-hari. Disektor pendidikan, Pandemi Covid-19 secara tidak langsung berdampak terhadap terciptanya transformasi sistem pendidikan yang dulunya proses pembelajaran secara tatap muka mulai diarahkan menjadi pembelajaran secara daring.

Kemajuan suatu bangsa sangat ditentukan oleh kualitas pendidikan sehingga kemajuan teknologi pendidikan yang semakin canggih harus mampu diimbangi oleh sumber daya manusia (SDM) yang handal dan terampil dalam menggunakan fasilitas teknologi informasi yang ada terutama komputer dan sarana internet, sehingga 
dengan perkembangan teknologi yang semakin meningkat, gurupun mampu beradaptasi mengikuti perkembangan teknologi tersebut dan mampu menggunakan fasilitas tersebut dengan baik [1]. Hal ini juga sesuai dengan Undang-Undang Republik Indonesia No. 14 tahun 2005 tentang Guru dan Dosen yang menjelaskan beberapa kompetensi yang harus dimiliki seorang guru profesional, salah satunya kemampuan guru dalam memanfaatkan teknologi informasi dan komunikasi (TIK) dalam proses belajar mengajar [2]. Keterampilan para guru terutama dalam pemanfaatan sarana teknologi merupakan salah satu faktor penting dalam proses peningkatan kualitas pembelajaran dan mutu guru sebagai tenaga pendidik di sekolah sehingga sudah seharusnya sekolah diharapkan mampu memberikan layanan pendidikan dengan sebaik mungkin bagi para peserta didik terutama dimasa pandemi Covid-19.

Dari hasil observasi ke SMPN 1 Anjir Pasar didapatkan, mitra masih mengalami kesulitan dalam memanfaatkan dan mengoptimalkan sarana teknologi informasi dan komunikasi terutama dalam hal pembelajaran secara daring. Dengan adanya kegiatan pengabdian kepada masyarakat ke SMPN 1 Anjir Pasar, diharapakan dapat membantu para Guru dalam memahami dan meningkatkan keterampilan Guru dalam memanfaatkan sarana teknologi informasi dan komunikasi terutama dalam hal pembelajaran secara daring dimasa pandemi Covid-19.

\section{KHALAYAK SASARAN}

Mitra Kegiatan Pengabdian kepada Masyarakat ini adalah 5 orang perwakilan Guru di SMPN 1 Anjir Pasar yang beralamat jalan Trans Kalimantan KM 27,5 Kecamatan Anjir Pasar, Kabupaten Barito Kuala.

\section{METODE}

Metode dari penyelesaian permasalahan mitra terdiri dari beberapa tahapan dalam pelaksanaannya diantaranya :

1. Metode presentasi berupa sosialisasi kegiatan untuk meningkatkan pengetahuan, sikap dan perilaku kelompok sasaran, terutama yang berkenaan dengan materi dan tujuan kegiatan yang dilakukan.

2. Metode pelatihan dan pendampingan tentang bagaimana membuat media pembelajaran 
berbasis multimedia menggunakan

Powtoon dan memanfaatkan media

Google Forms sebagai media ujian online.

3. Metode Praktek Mandiri dimaksudkan untuk memberikan kesempatan kepada para Guru untuk mempraktekkan secara langsung bagaimana memanfaatkan fasilitas teknologi informasi dan komunikasi terutama penggunaannya sebagai media pembelajaran dan media ujian online.

\section{HASIL DAN PEMBAHASAN}

Hasil dari kegiatan Pengabdian yang telah dilaksanakan di SMP Negeri Anjir Pasar, jalan Trans Kalimantan KM 27,5, Desa Anjir Pasar Kota II, Kecamatan Anjir Pasar, Kabupaten Barito Kuala pada tanggal 11 Februari 2021 dan 18 Maret 2021, secara garis besar mencakup beberapa komponen sebagai berikut:
1. Keberhasilan target jumlah peserta pelatihan, kegiatan pengabdian kepada masyarakat ini diikuti sesuai target awal yaitu 5 orang perwakilan Guru, bahkan pada pelaksanaannya peserta yang ikut berpartisipasi ternyata melebihi target awal karena hampir semua Guru ternyata ikut serta.

2. Antusias peserta dalam mengikuti kegiatan yang terlihat selama proses pelatihan, peserta pengabdian aktif dalam mengikuti rangkaian kegiatan pelatihan.

3. Adanya peningkatan tingkat pemberdayaan peserta yang dapat dianalisa melalui hasil evaluasi pengisian kuesioner online (google forms) baik freetest maupun posttest. Adapun peningkatan tingkat pemberdayaan peserta dapat dlihat pada tabel berikut :

Tabel 1 Hasil Freetest dan Postest

\begin{tabular}{|c|c|c|c|c|}
\hline No & Pertanyaan & Pra & Post & $\begin{array}{l}\text { Peningkatan } \\
\text { Tingkat } \\
\text { keberdayaan } \\
(\%)\end{array}$ \\
\hline 1 & adakah yang menggunakan media google forms saat pandemi covid 19 ? & 2 & 4 & 40 \\
\hline 2 & apakah anda mengetahui tentang google forms? & 2 & 5 & 60 \\
\hline 3 & apakah anda pernah menggunakan google forms? & 1 & 5 & 80 \\
\hline 4 & apakah anda bisa menggunakan google forms sebagai media ujian online? & 0 & 5 & 100 \\
\hline 5 & apakah anda pernah membuat video pembelajaran? & 1 & 5 & 80 \\
\hline 6 & apakah anda mengetahui tentang powtoon? & 0 & 5 & 100 \\
\hline 7 & apakah anda bisa menggunakan powtoon untuk membuat video pembelajaran ? & 0 & 5 & 100 \\
\hline \multicolumn{4}{|c|}{ Rata-Rata Peningkatan } & $80 \quad 17$ \\
\hline
\end{tabular}


pengabdian kepada masyarakat ini, maka dapat dilihat progres peningkatkan tingkat keberdayaan

Berdasarkan hasil analisa dan evalusi kuesioner freetest dan posttest kemampuan peserta pada kegiatan peserta yang cukup baik yakni mencapai rata-rata peningkatkan sebesar $80 \%$.

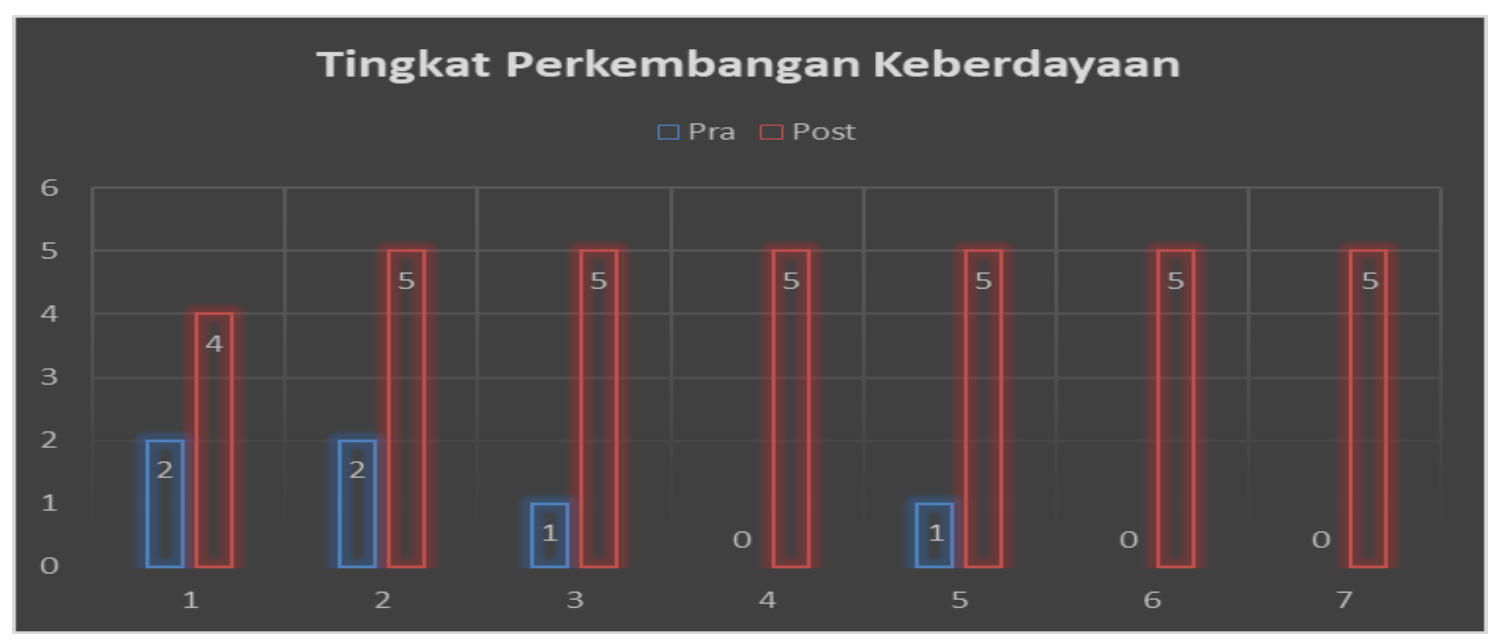

Gambar 1. Grafik Tingkat Perkembangan Keberdayaan
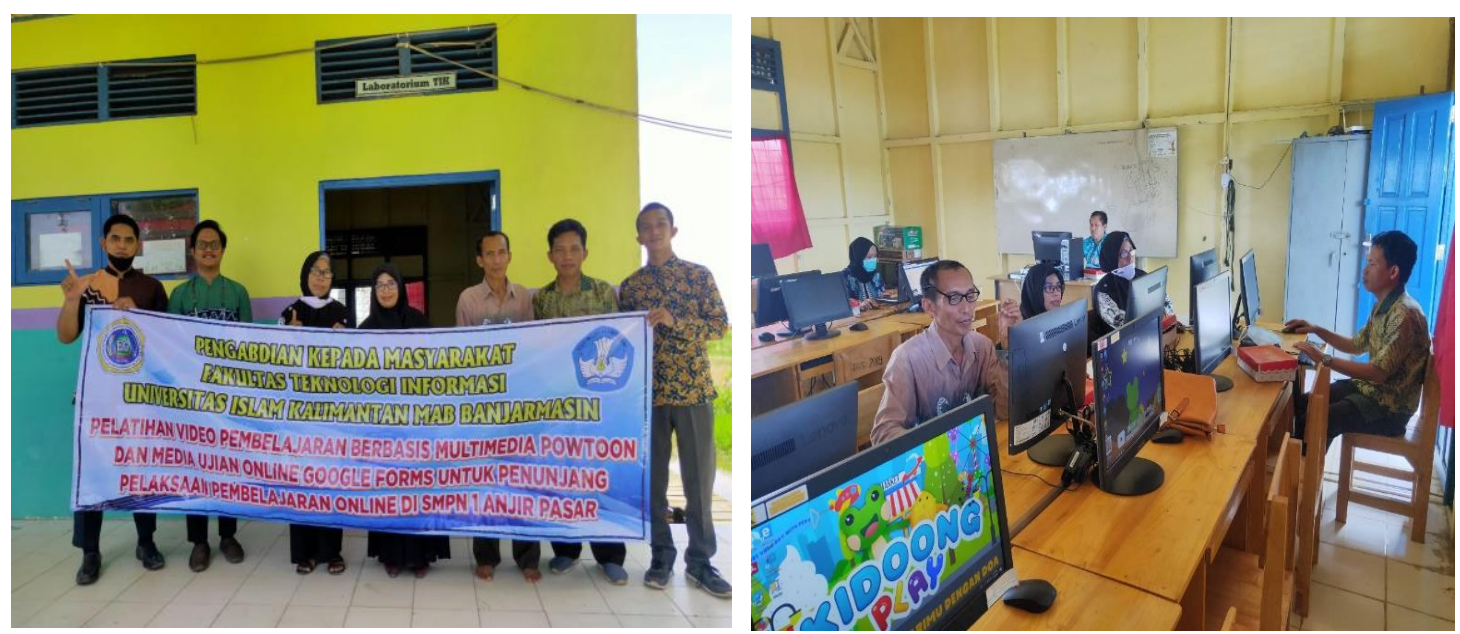

Gambar 2. Foto Kegiatan Pengabdian Hari Pertama 

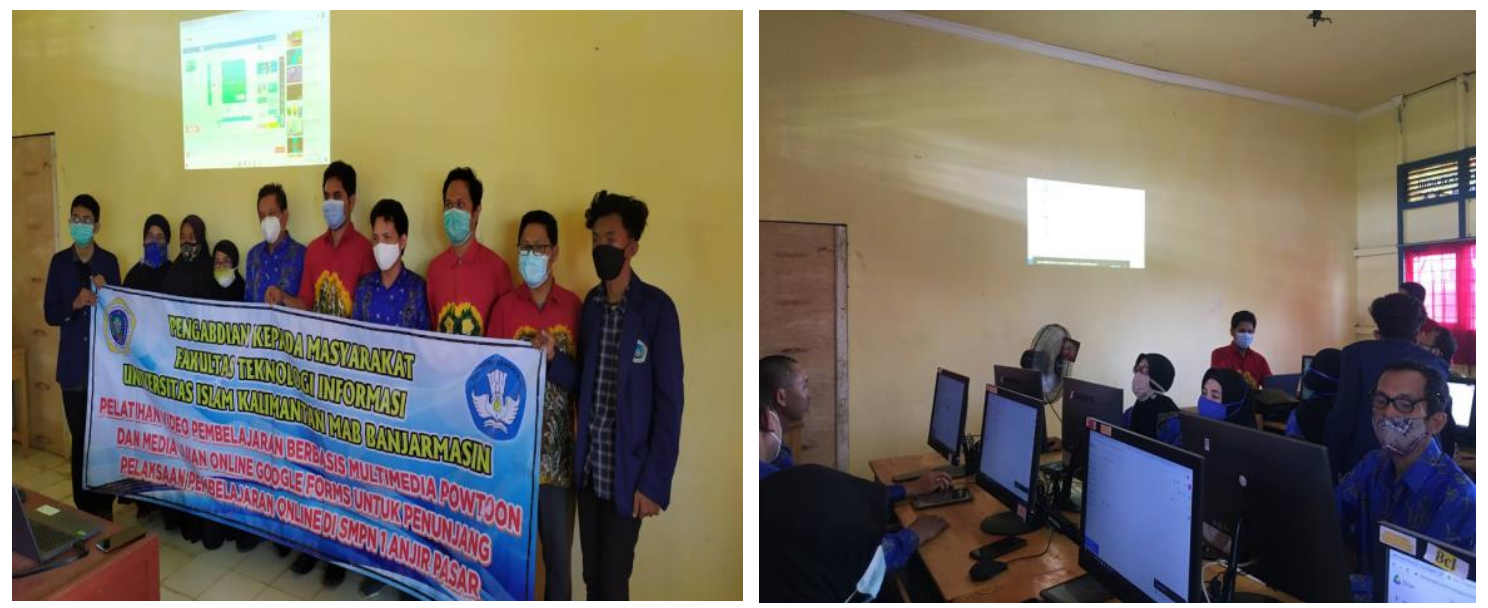

Gambar 3. Foto Kegiatan Pengabdian Hari Kedua

\section{KESIMPULAN}

Berdasarkan hasil pelaksanaan Kegiatan Pengabdian Kepada Masyarakat yang dilaksanakan di SMP Negeri Anjir Pasar, jalan Trans Kalimantan KM 27,5, Desa Anjir Pasar Kota II, Kecamatan Anjir Pasar, Kabupaten Barito Kuala pada tanggal 11 Februari 2021 dapat diambil beberapa kesimpulan sebagai berikut:

1. Terlaksananya kegiatan Pengabdian Kepada Masyarakat ini membantu membantu mitra yaitu SMPN 1 Anjir Pasar yang masih mengalami kesulitan dalam memanfaatkan sarana teknologi informasi dan komunikasi terutama pada proses pembelajaran secara daring dimasa pandemi Covid-19.
2. Ketercapaian tujuan pengenalan materi dan pelatihan diukur dari hasil evaluasi praktik peserta maka kegiatan ini dinilai telah berhasil dapat membantu Guru dalam memahami dan memanfaatkan sarana teknologi informasi dan komunikasi dengan baik serta mampu menggunakan fasilitas teknologi informasi tersebut sebagai sarana media penunjang dalam pelaksanaan pembelajaran secara daring dimasa pandemi Covid-19.

3. Antusias peserta dalam mengikuti kegiatan yang aktif dalam setiap sesi.

4. Kemampuan peserta dalam penguasaan materi yang dinilai cukup baik. 
Berdasarkan hasil evaluasi di lapangan terdapat saran untuk kegiatan pengabdian ini yakni perlu adanya keberlanjutan pelaksanaan program dimasa yang akan datang terutama menghadapi perubahan sistem pendidikan di masa pandemi Covid-19 yang masih berlangsung agar dapat maksimal dalam pelaksanaan pembelajaran secara daring.

\section{DAFTAR PUSTAKA}

Azis, T. N., \& Shalihah, N. M. (2020). Pengembangan Evaluasi Pembelajaran Berbasis Google Form. Tawazun: Jurnal Pendidikan Islam, 13(1), 54. https://doi.org/10.32832/tawazun.v $13 i 1.3028$

Birokrasi, K. P. A. N. dan R. (2020). Survei Online, Salah Satu Cara Perbaikan Pelayanan Publik di Masa Pandemi Covid-19. 23-25.

Dewan Perwakilan Rakyat Indonesia. (2005). Undang-Undang (UU) tentang Guru dan Dosen Nomor 14. Dewan Perwakilan Rakyat Indonesia, 2.

Hadiwiyati, R., \& Ayu Ithriah, S. (2020). Pelatihan Pembuatan Kuis Online Menggunakan Google Form Untuk Guru Smk Unitomo Surabaya Training With Online Quiz Using Google Form For Teachers Of SMK Rizka Hadiwiyanti, 1 ) Syurfah Ayu Ithriah PENDAHULUAN Seorang pendidik memerlukan strategi, metode d. Jurnal Pengabdian Pada Masyarakat, 8(1), 106-110.

Handayani, M., Hendra, M., \& Nadia.
(2020). Evaluasi Pembelajaran Daring Selama Pandemi Covid-19 Pada Jurusan Akuntansi Politeknik Negeri Banjarmasin.

Heryanto, G., \& Rahayu, S. (2021). The Influence of Powtoon Media in Teaching Listening. PROJECT (Professional Journal of English Education), 4(1), 86.

Istiqomah, I., Indonesia, U. I., Sulistyorini, S., \& Indonesia, U. I. (2021). Media Teknologi Untuk Teaching Assessment : Live Worksheet Dan Google form Media Teknologi Untuk Teaching Assessment : Live Worksheet Dan Gform. March.

Karyadiputra, E., Mahalisa, G., Sidik, A., \& Wathani, M. R. (1967). Pengembangan Kreativitas Anak Asuh Berbasis Ti Dalam Menanamkan Nilai Wirausaha Pada Asrama Putera Panti Asuhan Yatim Piatu Dan Dhu'afa Yayasan Al-Ashr Banjarmasin. Al Ikhlas, 4(April), 5-24.

Kozhuharova, D. (2019). Creating Tests With Google Forms.

Педагогически Форум, 7(1), 6370.

Muin, A. A., Kumala, S., \& Karyadiputra, E. (2019). PKMS Peningkatan Kompetensi Guru Dan Pengembangan Perangkat Pembelajaran Berbasis It Guna Menunjang Pelaksanaan Kurikulum 2013 Pada Smp Negeri 1 Anjir Pasar Desa Anjir Pasar Kota Ii Kec. Anjir Pasar Kab. Batola. Al Ikhlas, 5(x), 78-86.

Msn.com. (2020a). Covid-19 Ubah Sistem Kerja Pemerintahan. 1-6.

Msn.com. (2020b). Kemendagri Dorong Inovasi Pelayanan Publik 
di Daerah Saat Pandemi Covid-19.

Pasifika, melania. (2020). Mengawasi

Pelayanan Publik Di Masa

Pandemi Covid-19.

Ombudsman.Go.Id, 1-16.

https://ombudsman.go.id/artikel/r/a rtikel--mengawasi-pelayananpublik-di-masa-pandemi-covid-19

Rahayu, E., Febriyana, M., \&

Tussadiah, H. (2019). Analysis of Powtoon-Based Learning Media
Development in Indonesian

Language Subjects. 773-779.

Sivakumar, R. (2019). Google Forms in Education. Journal of

Contemporary Educational

Research and Innovations, 09(01), 35-39.

Tarmuji, A. (2020). Panduanpembuatan-ujian-online-dengangoogle-form. July. 